\title{
TOOLS TO RETAIN ADDED VALUE IN DAIRY FARMS: THE SOUTH KOREA CASE
}

\author{
Mirco Corazzin 1 , Markus Schermer², Seung-Yong Park ${ }^{3 *}$
}

\author{
${ }^{1}$ Department of Agricultural, Food, Environmental and Animal Sciences, University of Udine, \\ Udine, 33100, Italy \\ ${ }^{2}$ Department of Sociology, University of Innsbruck, Innsbruck, A-6020, Austria \\ ${ }^{3}$ Department of Animal Science, Yonam College, Yonamro, Cheonan, 31005, South Korea \\ * Corresponding author: E-mail: psyonam@paran.com
}

Citation: Corazzin, M., Schermer, M., Park, S.Y., 2017. Tools to Retain Added Value in Dairy Farms: The South Korea Case. J. Asian Rur. Stud. 1(2): 81-96

\begin{abstract}
South Korea witnessed an increase in the average size of dairy farms over the past decade, probably because of high production costs especially relevant for farms with less than 40 heads. Korean dairy farms have production costs that are $63.9 \%$ higher than the international milk price, and the producer support by the Korean government is 2.5 times higher than the average of the Organization for Economic Co-operation and Development countries. Considering a possible reduction of public support, and the increasing market openings, one of the objectives for farmers would be to try retaining on farm a higher added value for their dairy products such as cheese and fermented milk. Out of this perspective, and on the basis of a questionnaire that involved the great part of the farmers that produce cheese, this paper describes three possible tools for the valorization of dairy products: short supply chains and direct marketing, dedicated supply chains with certification and labels and the approach values based supply chains.
\end{abstract}

Keywords: Milk Price; Dairy Products; Short Supply Chains; Values Based Supply Chains; Dedicated Supply Chains

\section{Introcution}

In South Korea, the majority of dairy farms $(2,751$ farms; $48.8 \%$ of the total) keep from 50 to 100 cows, followed by farms $(1,647$ farms; $29.3 \%)$, with less than 50 , and farms $(1,235$ farms; $21.9 \%)$ with more than 100 dairy cows. However, some trends need to be taken into account. The number of dairy cattle has decreased by $14.0 \%$, while the number of dairy farm households has decreased by $38.7 \%$ over the last decade (KOSIS, 2014). These figures indicate a rapid restructuring of the milk sector. Indeed, while the number of farm households with more than 100 heads has increased $(1,235 ;+101.8 \%$ within ten years), farm households with less than 100 heads decreased by $48.7 \%$ over the last ten years. The same trend can be observed as the number of animals in farm households with more than 100 heads has increased by $108.3 \%$, and decreased by $38.9 \%$ in the others (KOSIS, 2014). The reasons can be probably attributed to the gap in production costs for milk that varies between $55.9 € / 100$ liters of milk in farms with more than 80 heads, and $66.7 € / 100$ liters of milk in farms with fewer than 40 animals, although the average cost of production $(56.9 € / 100$ liters of milk) has been fairly stable 
from 2012 to $2014(+1.5 \%)$ (KOSIS, 2014). While this gap indicates economies of scale another factor for the generally high production costs can be attributed to cattle feeding. Indeed, the domestic supply of high quality forage is about the $30 \%$ of the total forage required by the cattle sector (Seo, 2005). A survey conducted in Italy, (Borreani et al. 2013) showed that a reduction of the proportion of feedstuff purchased off farm (form 38 to 23\%) and an increased dry matter and protein self-sufficiency (form 62 to $77 \%$ and form 35 to $54 \%$, respectively) reduced the feeding costs of about the $28 \%$. From this point of view, increasing domestic forage production through greater productivity and acreage, and the correct choice of the forage species seems to be a promising strategy to reduce production costs (Borreani et al., 2013; Seo, 2005).

Despite of production costs, farm-gate milk price $(88.7 € / 100$ liters; KDC, 2015) is still much higher than the international milk price $(34.7 € / 100$ liters; CLAL, 2014) or that of Japan (71.7 €/100 liters, KREI, 2014). The high milk price has led consequently farmers to overproduce daily more than $100 \mathrm{~kg} / \mathrm{farm}$ (KDC, 2015). It can be attributed to a high level of support mainly based on market price. According to the Organization for Economic Co-operation and Development (OECD, 2014), currently the producer support, (expressed as percentage of gross transfers from taxpayers to producers on gross farm return for milk sale) is about the 50\%. In general, the producer support by the Korean government is 2.5 times higher than the average of OECD countries (OECD, 2014). Inevitably, a support of this level causes a distortion of the market, and considering also the high production costs, make this country closed off from the world market. However, because of world trade more and more globalized and with fewer barriers, in the near future also the producer support system in South Korea is likely to change. This process is already taking place, indeed the producer support has been considerably reduced during the last decades, (70\% in 1988, 68\% in 2003; 52\% in 2013; OECD, 2004; 2014). Since 1994, with the Uruguay Round WTO agreement, South Korea has gradually started to open its dairy market to imports (Lee et al., 2006). At the same time, the export of dairy products is very limited (OECD-FAO, 2014). In South Korea, the fresh milk market has had a fluctuating trend over the past decade, with a reduction of $3.5 \%$ from 2012 to 2014, but with an increase of $2.1 \%$ from 2004 to 2014 reaching 1,356,301 tons. Conversely, the production of fermented milk increased by $9.1 \%$ from 2004 to 2014, and by $25.8 \%$ from 2008 to 2014 when reached 572,418 tons (KOSIS, 2014). In general, cheese production decreased by $2.1 \%$ in the last ten years, but it has to be considered that, after sharp drop from 2010 to 2012 (17.8\%), an increase from 2012 to $2014(5.6 \%)$ was observed. The consumption of cheese is constantly increasing (+85.3\% from 2004 to 2014 ) reaching 117,829 tons, which is $395.6 \%$ higher than the domestic production (KOSIS, 2014). These data mainly highlight that there is a large gap between domestic production and demand for cheese, and this gap is filled with imports, which are likely to rise further in the coming years (OECD-FAO, 2014; Corazzin et al., 2015).

Consequently, the country will be more dependent on imports, which requires activities to improve the situation. Besides the efficiency of production on farm we suggest that the organization of the supply chain provides scope for improvement. So far, there are no studies on farm level about constraints that limit the development of cheese sector. Therefore, the aim of this paper is to understand the main problem of the Korean dairy sector as perceived by dairy farmers and propose some solutions. We base 
our assessment on an exploratory survey among farmers and consumers and put the results in relation to best practice examples as found in other parts of the world.

\section{Methods}

Two questionnaires were considered. One was randomly submitted by surface mail to 76 dairy farmers who are operating on small scale farm dairies in Korea. Nineteen valid replies with complete answer were collected (25\% of the total). The questionnaire was aimed to gather the basic data on production facilities, production scale and the varieties of dairy products, and also to collect their opinions on regards with the awareness of value chain, and the difficulties being faced with the other dairy chain actors.

The second questionnaire was submitted to 160 randomly selected consumers from those passed by food shops, called "Natural food shops", selling eco-friendly agriculture products in Seoul. This survey was conducted from October 2015 for two months by face to face interview with the consumers at street table. The $67 \%$ of the consumers answered completely. Consumers were asked to evaluate the dairy products, and their awareness for farm tour at farm dairies.

In both questionnaires a part on the perception of the factors affecting the management and development of the dairy farms was included.

\section{Results}

\subsection{Production Scale and Dairy Products}

In South Korea, an increase of on farm cheese making was already observed in the past decade, a total of 70 dairy farms assumed to run their own dairies and 30 dairy farms run tour programs including cheese making, and calves feeding. This trend has been widespread in dairy farms in spite of high cost of farm-gate milk. However, the production quantity of milk has been increased consistently more than the quantity of milk consumption, resulted in surplus milk problem. Consequently, a strong desire to sell the milk products processed in their farms to the consumers has been sprout out in their mind instead of reduction of milking. Financial support by the government makes them to equip with the modern cheese machines. Production capacities of farm dairies are in the range of $200 \mathrm{~kg}$ to $1,000 \mathrm{~kg}$ per day and produce twice a week, mainly fermented milk and pizza cheese with stringiness, grilled cheeses, such as Haloumi and Queso-Blanco, and ripening cheeses, such as Gouda, Feta, and Camembert type cheese (Figure 1). 


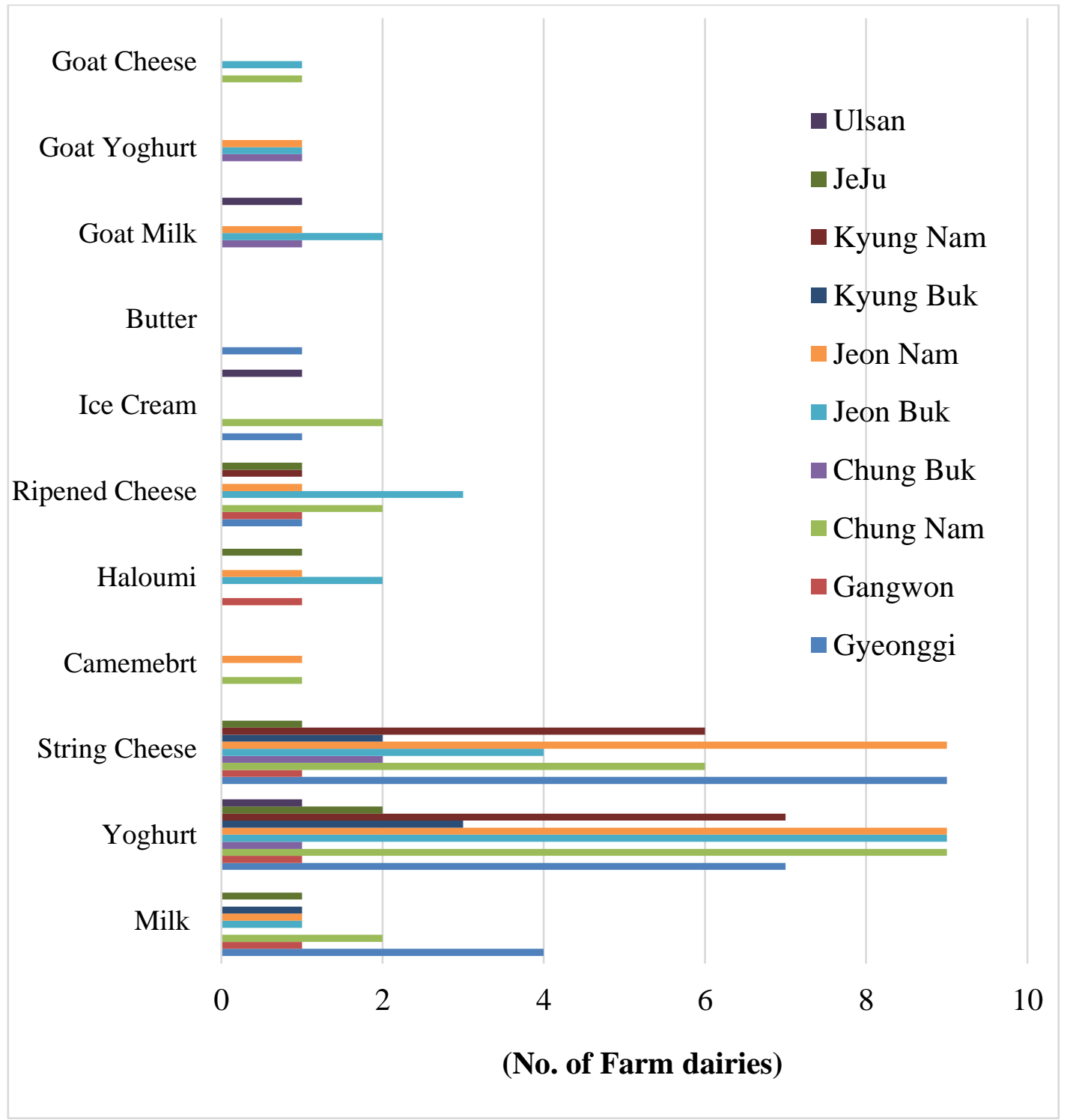

Figure 1. Types of milk products manufactured on farm dairies of Korea by provinces.

\subsection{Consumers experiences}

The $23.9 \%$ of the consumer involved in the survey did not aware of existence of tours at farm dairies itself, $54.8 \%$ of them knew, but not visited yet and $21.29 \%$ visited the tours at farm dairies (Figure 2). 


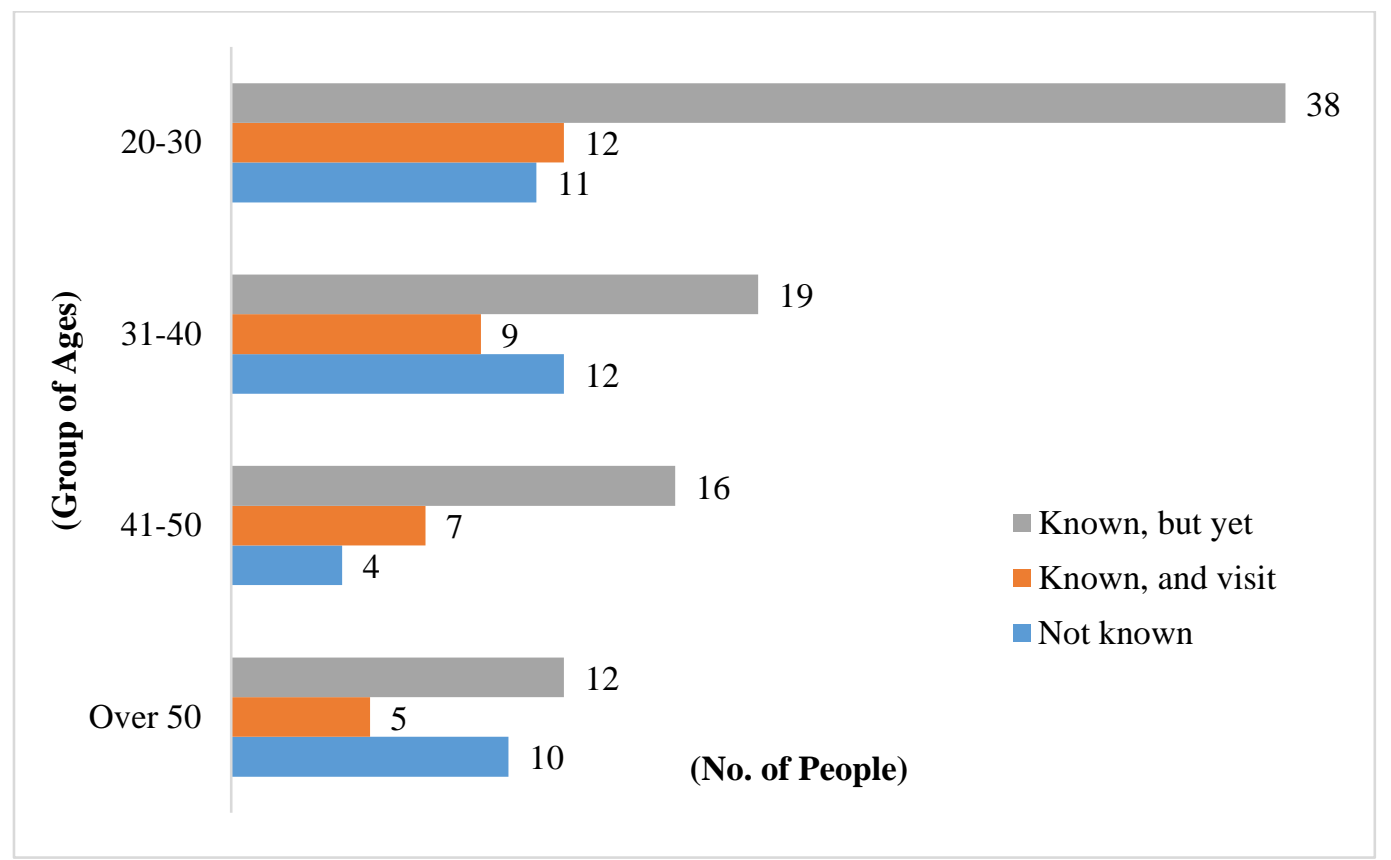

Figure 2. Korean consumers' awareness of farm tour program in farm dairies.

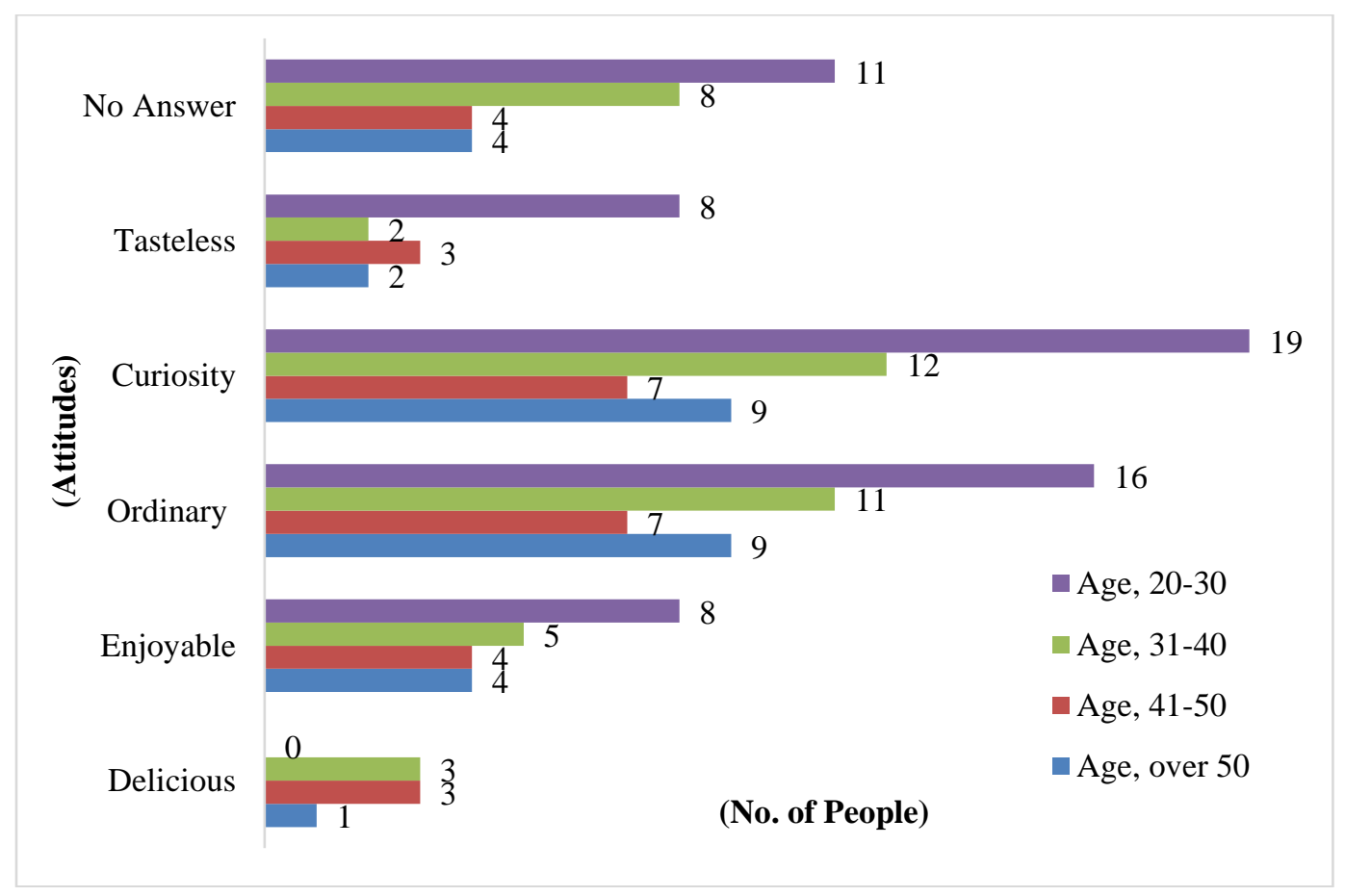

Figure 3. Korean consumers' attitude toward ripened cheese while travelling the overseas trips by age groups. 
Korean consumers, who have experienced travelling overseas trips, showed different attitudes in response to cheese foods served at restaurant and at the market. There main part of the consumers eats cheese with a curiosity feeling (Figure 3 ).

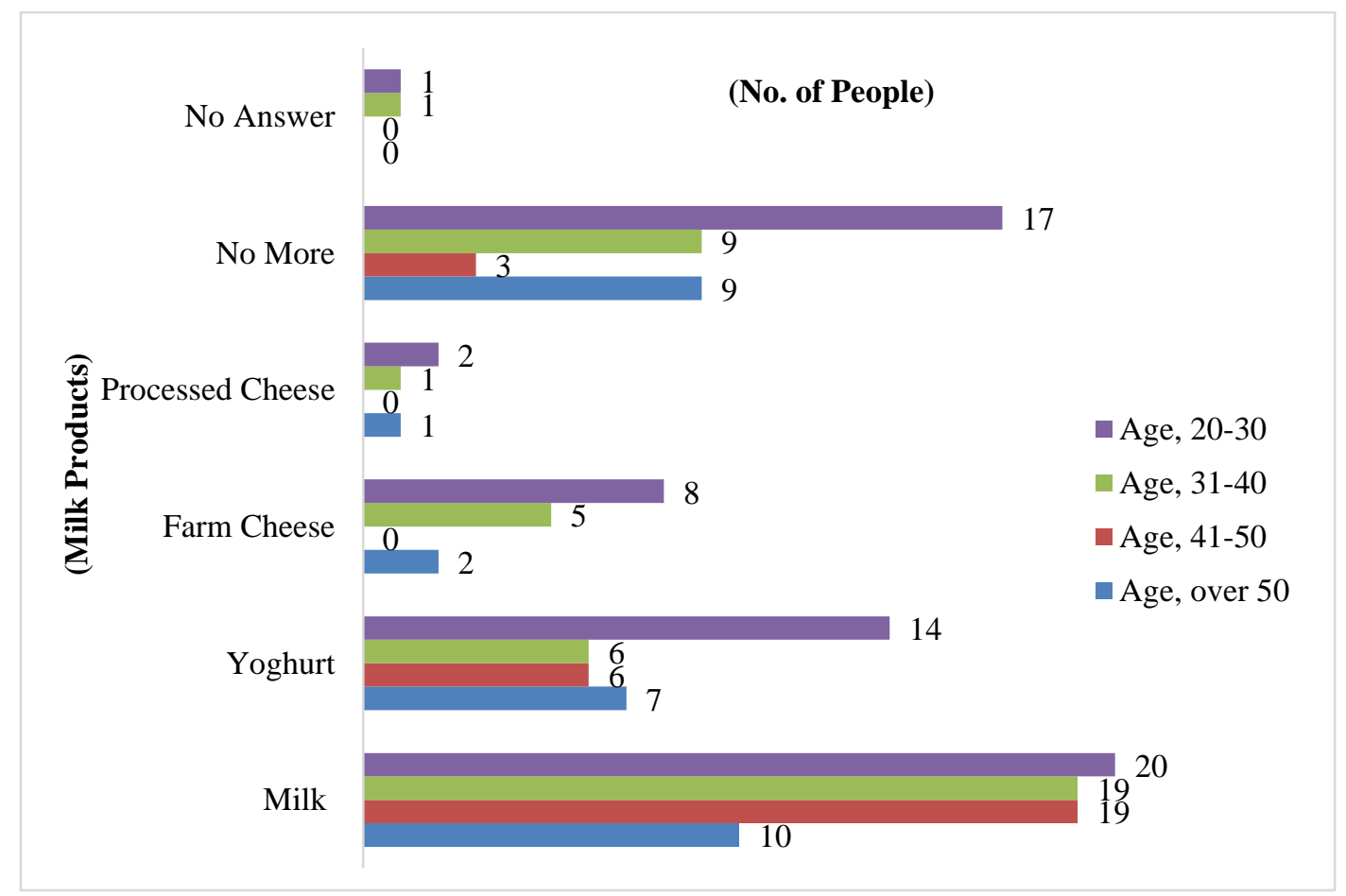

Figure 4. Purchase intentions of value-added milk products by Korean consumers.

Moreover, the consumers have intentions to purchase more milk than any other milk product in all age groups (Figure 4). This result seemed to be influenced by the high price of cheese. Korean consumers' expectations about farm products were summarized by Park et al. (2017) that showed that Korean consumers perceived farm dairy products are lacking variety and they complained about the high price. Farmers although being concerned about lacking variety of products considered the price as tool to compensate the high costs of farming and of dairy products processing.

\subsection{Perception of the factors affecting the management and development of the dairy farms}

From the questionnaires' analysis, the limiting factors affecting the management and development of the dairy farms were:

- high production costs owing to small scale production, e.g. the farmer cheeses have a price approximately double than the market price of imported cheeses;

- lack of appropriate information on demands of dairy products;

- deficiency in developing technology for new products;

- deficiency in the standardization of production facilities for a variety of products;

- expensive payments for quality verifications and strict inspections regulations and the need for an alternative policy of quality control for replacing HACCP;

- need for cooperative cellars for ripening of cheese; 
- improve the products' labelling;

- low information provided to the consumer on the superior quality of small-scale dairy farm products compared to general and imported dairy products;

- low management of marketing channels;

- increasing competition among dairy farms;

- need for cooperative in marketing;

- expensive costs for dispatch service.

Based on the results of the questionnaires, the sharing of value along the dairy supply chain and the consumer needs were examined. Supply chains for farm milk products in Korea shares directly and indirectly, $58.6 \%$ and $41.4 \%$, respectively. As depicted in Figure 5, collaboration with neighbor farm's shop and farmers' cooperative were quite in a low portion.

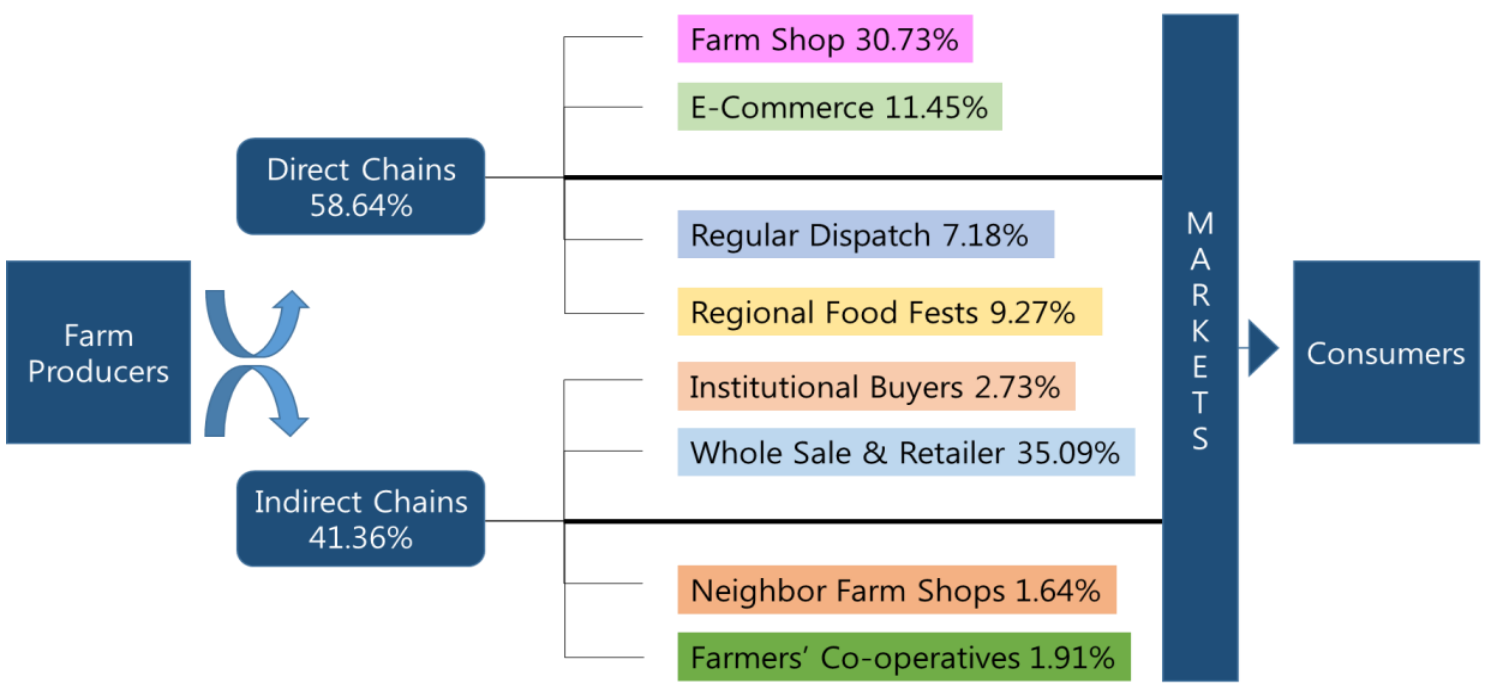

Figure 5. Shares of direct and indirect supply chains for farm milk products in Korea

This exploratory survey gives a first indication on the situation of on farm dairy processing in South Korea. In the following sections we want to place these results into the wider context of international discussions on improving the revenue for farmers and meeting consumer expectations. First we examine literature on the price asymmetries between actors along the chain and various stages of processing, and then we look at consumer expectations and requirements for consumer information.

\section{Contextualization of results in international literature}

\subsection{Sharing value along the supply chain}

Many studies conducted in USA showed that the transmission of the milk price along the supply chain is positive asymmetric (Stewart and Blayney, 2011; Kim and Ward, 2013). It means that the retail price responds more fully and more quickly with an increase rather than with a decrease of the milk price at farm level (Capps and Sherwell, 2005). From this point of view, to study the price transmission along the dairy chain in South Korea is complex given the public support and the peculiarities of the production in this country (Kim and Ward, 2013). However, also in European countries such as 
Slovenia, United Kingdom, and Denmark, where there is a strong economic public support to farmers, a positive asymmetric milk price transmission along the dairy chain was found (Oliveira et al., 2014). It is very interesting to highlight that the asymmetry is increasing with a higher added value of the dairy product (Oliveira et al., 2014). In other words and in general terms, the cheese supply chain present a higher asymmetry than milk supply chain. The European Union (2009) explained that this asymmetry can be due to many factors such as: perishable nature of milk, the high number of actors along the chain, the structure of the market that is oligopolistic for dairy, imperfect information about price, and public support.

Another aspect to be considered is the product value, and the formation of the retail price of milk. In United Kingdom the farm-gate price for milk is about $33 \%$ of the retail milk price, in Germany it is about the $40 \%$ of the price that consumers pay for fresh whole milk, in France it is about the $32 \%$ of the UHT retail milk price, the other part of the value is formed during the phases of processing and distribution (European Union, 2009). A similar situation can be observed in USA. Schnepf (2013), considering three years average (2009-2011), reports that the dairy farm achieve a share of $29.4 \%$ as compared to the final retail price for dairy products.

In short, the interest of dairy farmers should aim to sell products with high value added such as cheese, aggregate supply, and engage in short supply chains, not only because of the asymmetrical distribution of revenues, but also to retain the higher possible level of value added. Moreover, it is interesting to point out that even in a cheese chain, the farmer is the economic actor who has the greatest interest in the economic success of the chain (Bertazzoli et al., 2009).

\subsection{Requirements for traceability and consumer information}

Moreover such aspirations meet with changing demands from the consumer side. Over the last decades food traceability, defined by the European Regulation 178/2002 as "the ability to trace and follow a food, feed, food producing animal or substance intended to be, or expected to be incorporated into a food or feed, through all stages of production, processing and distribution", has become of increased importance to consumers. Indeed, after recent food safety issues, such as Bovine Spongiform Encephalopathy (BSE) and avian flu, consumers have become more and more interested in the transparency of the production process, and, consequently, want to know about the provenience of the raw materials and the different stages of production (Dalvit et al., 2008). The traceability of food has become so important that, in recent years, the scientific community has explored and tested numerous systems and methods, sometimes very complex, to enhance traceability, such as PCR, spectrophotometric methods, chromatography, stable isotope ratio mass spectrometry, near infra-red absorption techniques, and DNA, enzyme immunoassays, and metabolome analysis (Lees, 2003). As reported by Dalvit et al. (2008), traceability is perceived to a guarantee safety, health, and quality for the consumer. Short and dedicated supply chains allow easier and more reliable traceability of dairy products. While technical methods to increase traceability and control of providence may assist to localize products from outside the region in long mainstream supply chains, e.g. in supermarkets, short supply chains allow building and maintaining relations of trust.

Correct and timely information to consumers is another key issue for the success in 
the sale of products which may be provided by short and dedicated supply chains. Indeed Howard (2006) showed in a wide survey conducted in USA that about the $60 \%$ of the consumer would like to have more information about the product. Lahne et al. (2014) demonstrated that information is able to modify the sensory perceptions of the consumers. Also Romanzin et al. (2015) argued that information is able to strongly influence the preference of consumers for certain products. In their experiments the above cited authors offered two types of cheese to consumers, the first produced from dairy cows grazing on mountain pastures and the other from dairy cows fed on a haybased diet. When the consumers assessed the two cheeses in blind condition they made no difference in their preferences, but when the cheeses were tested linked with information on the feeding conditions, the first cheese obtained a liking score significantly higher than the second one. Moreover, many studies showed that the place of origin of a product has a key role in the purchasing decision of the consumers, due to their emotional involvement (Verleght and Steenkamp, 1999; Caporale and Monteleone, 2004; Braghieri et al., 2014). Zheng (2014) reviewed that consumers prefer to buy local food in order to sustain local farms, and because they believe that farmer improves the animal welfare, and that the product is healthier. These results are confirmed also by the study of Onozaka (2010) that ranks factors for consumer's purchasing decisions according to the following order: personal health benefit, support of the local economy, farmers receiving a fair return and maintaining local farmland.

Another important aspect is information about the production system. Indeed Napolitano et al. (2010) suggest that the information about production system is one of the most important factors able to increase the willingness to pay by consumers. Kapsosderová and Nagyová (2005) highlighted in a survey that included more than 200 consumers, that besides the price the place of origin and the indication of the producer is decisive for the purchase of a product. In this respect dedicated supply chains with systems of certification and labels may play an important role.

Another element to consider is the possibility of increasing the functionality of the products of animal origin, and make they more acceptable to consumers who are more and more aware of the link between food and health. From this point of view, it is known that animal's feeding and the fresh forage in particular, are able to improve the nutritional properties of dairy products (Romanzin et al., 2013). On the other hand, in a study conducted in Italy, the substitution of corn with alfalfa or permanent grassland silage, was able to reduce milk production costs and increase the income over feed costs of the farmer (Borreani et al., 2013).

\section{Possible strategies}

Both aspects, Value distribution along the supply chain and consumer expectation suggest that short supply chains and direct marketing, dedicated supply chains with certification and labels and the improved coordination in values based supply chains are options to improve the situation. They are able to meet farmers' requirements, and to combine consumer concerns with the aspiration of primary producers to increase their share of the consumer price. Therefore, we examine the potential of such interventions in the following sections. 


\subsection{Short dairy supply chains}

The concept of supply chain is rather complex, Valeeva et al. (2005) suggest to divide the production process into four phases: food (including the input factors for a farm, such as the animal feeds), farm, industrial process (transport, treatment or transformation of milk) and consumer (consumption and retail establishment). Moreover, dairy supply chains include in each phase subjects directly involved in the production process, and subjects or organizations that play a role in management or support (banks, producer cooperatives, etc.). The length of the supply chain is related to the number of actors that take part to the production process (Bovolenta, 2007). A short supply chain means that the farmer, in addition to producing milk, is also involved in other steps of the supply chain such as the transformation and/or the direct sales of the product. This allows in the sense of a deepening strategy (van der Ploeg and Roep, 2003) capturing more value on the farm and increasing the contribution to rural development and a vital countryside. Most well-known forms include farmers markets, farms gate sales and home delivery via box schemes. By cutting out middle men primary producers may retain a higher proportion of the end consumer price.

However, the goal of short supply chains is not only to maximize the value added retained by producers, but also to increase the product recognition by consumers, by increasing the information about the product, and providing more possibilities to guarantee the traceability (Bovolenta, 2007). In fact, short supply chains allow valorizing and transmitting so-called positive externalities related to the production process more easily to the consumer. Bovolenta et al. (2011) include in their account of positive externalities connected to mountain production systems, effects on the production area (e.g. landscape features important for tourism), on forage quality (the composition of alpine pastures including a high proportion of herbs) included in animals' diet, as well as characteristics of animals (e.g. special traditional breeds adapted to mountain conditions) and farming management practices (enhancing biodiversity or animal welfare).

Finally, a short dairy supply chain potentially valorizes the reputation of the farm, and the peculiarity of a product, and consequently allows obtaining a product clearly differentiated on the market. Furthermore, the direct feedback from consumers in short supply chains may have some positive implications on motivational aspects of producers, especially farmers in mountain regions of the European Alps are often in part time farming situations and do not depend solely on the revenue of product sales. However, to retain the farming structure needed for viable rural development, motivational aspects to continue farming are crucial, especially for young farmers who are in the process of taking over the farm.

\subsection{Dedicated supply chains with labels}

As discussed previously, information on the dairy product plays a key role to drive and influence the purchasing decisions of consumers and short supply chains make the transmission of these information easier. In this respect, the use of official labels is another possibility that can be applied both within and outside of short dairy supply chain systems. Such labels help to establish dedicated supply chains that may differentiate products from anonymous generic mass products even if not sold direct to the end consumer or within certain region. One way is the indication of a certain region 
of production. The Council Regulation (EC) No. 510/2006 defines two different geographical indication labels, the Protected Designation of Origin (PDO) for food that are produced, processed and prepared in a particular area using well recognized knowhow, and the protected geographical indication (PGI) for products that are linked to a particular area for at least one of the stages of production, processing or preparation (European Commission, 2015). The main aim of these labels is to protect specific production methods or to tie the products to a certain region. Bérard and Marchenay (2007) distinguish between local food and localized food products and production, such that local food is locally-made while localized food has a cultural identity. Localized products valorize in contrast to local products the image of a certain region or of a certain production process if sold outside the region, often on a global scale (e.g. like Camembert from the Normandy or Parmesan cheese). A second type of label is "organic production" as defined by Council Regulation (EC) No 834/2007 as food obtained by a production system that adopt best environmental practices, preserves and favors animal and plant biodiversity, maintains natural resources, and favors animal welfare. Despite the fact that specific requirements for organic certification may vary between countries around the world, the label shares common basic principles. Adherence to these labels oblige the producers to comply with a product specification under the control of a third party official body, moreover, these labels allow to reduce the information asymmetry that characterizes the dairy products (de Brito et al., 2015), and the official body becomes guarantor of the quality of the product itself. On the other hand, being subject to constraints and rules, the label system implies an increase of production costs.

Garavaglia and Marcoz (2014), considering Fontina cheese, showed that Italian consumers are willing to pay more for PDO products, conversely, conflicting results were reported by Bonnet and Simioni (2001). Indeed, to quantify the increase in value of PDO products is difficult because it depends on many factors such as the intrinsic product differentiation, and the marketing strategies (Areté, 2013)

\subsection{Values based food chains}

Another strategy for retaining the value added on the farm is the concept of "values based food chains". This concept perceives no longer the farm as an independent element within the economic system, but as part of a horizontal and vertical network with processors and retailers (Garcia Perez and Garcia Martinez, 2007). The concept suggests a horizontal integration of farms as well as a vertical one. Horizontal integration of producers is effected most commonly by forming cooperatives. This is particularly necessary when farms operate on production levels, which require pooling of volume to ensure a sufficient and constant presence on the market of the product (Stevenson and Pirog, 2008). The forming of horizontal networks allows reducing fixed production and transaction costs and facilitates economies of scale. Horizontal coordination increases the transparency of market price and may result in a shift of relationships between farmers from competitors to partners. (Lazzarini et al., 2001; Garcia Perez and Garcia Martinez, 2007; Stevenson and Pirog, 2008, Schermer, 2015). Moreover, it may increase the bargaining power, both for sale and purchase of assets. At the same time, the values based food chain system proposes a vertical integration of all the actors along the supply chain. The aggregation of producers is complemented by a careful selection of partners in processing and retailing. This leads to long term 
partnerships of enterprises with the same values attached to products. Together such supply chains can transmit the key quality aspects of products through the entire supply chain down to the final consumer. This allows creating and maintaining a high quality level, which differentiates them from other products in the market (Stevenson and Pirog, 2008). The shared values are not restricted to those attached to products, but include also fair relationships between upstream and downstream partners. In this case producers neither act as price setters like in direct marketing relations nor as price takers as in mainstream mass markets, but they negotiate prices in an atmosphere of respect and knowledge of mutual possibilities and restrictions. If the farmers' cooperative maintains the ownership over the brand, they can reduce the power asymmetry towards retailers (Stevenson and Pirog, 2008; Schermer, 2015). Schermer and Furtschegger (2013), show in an empirical case study of the cooperative BioAlpin in Austria that the success of the horizontal and vertical integration of the food value based chain, as well as the increased profit for the farmers involved are related to the regional embeddedness of the chain. This relates to a large extend also to the trust and personal interaction between different chain partners. Pauwelyn (2014), examining the organic sector in Flanders Belgium, concludes that the highest performance of this kind of supply chain can be achieved if the profit is fairly distributed, and the information flow relevant and complete along the chain.

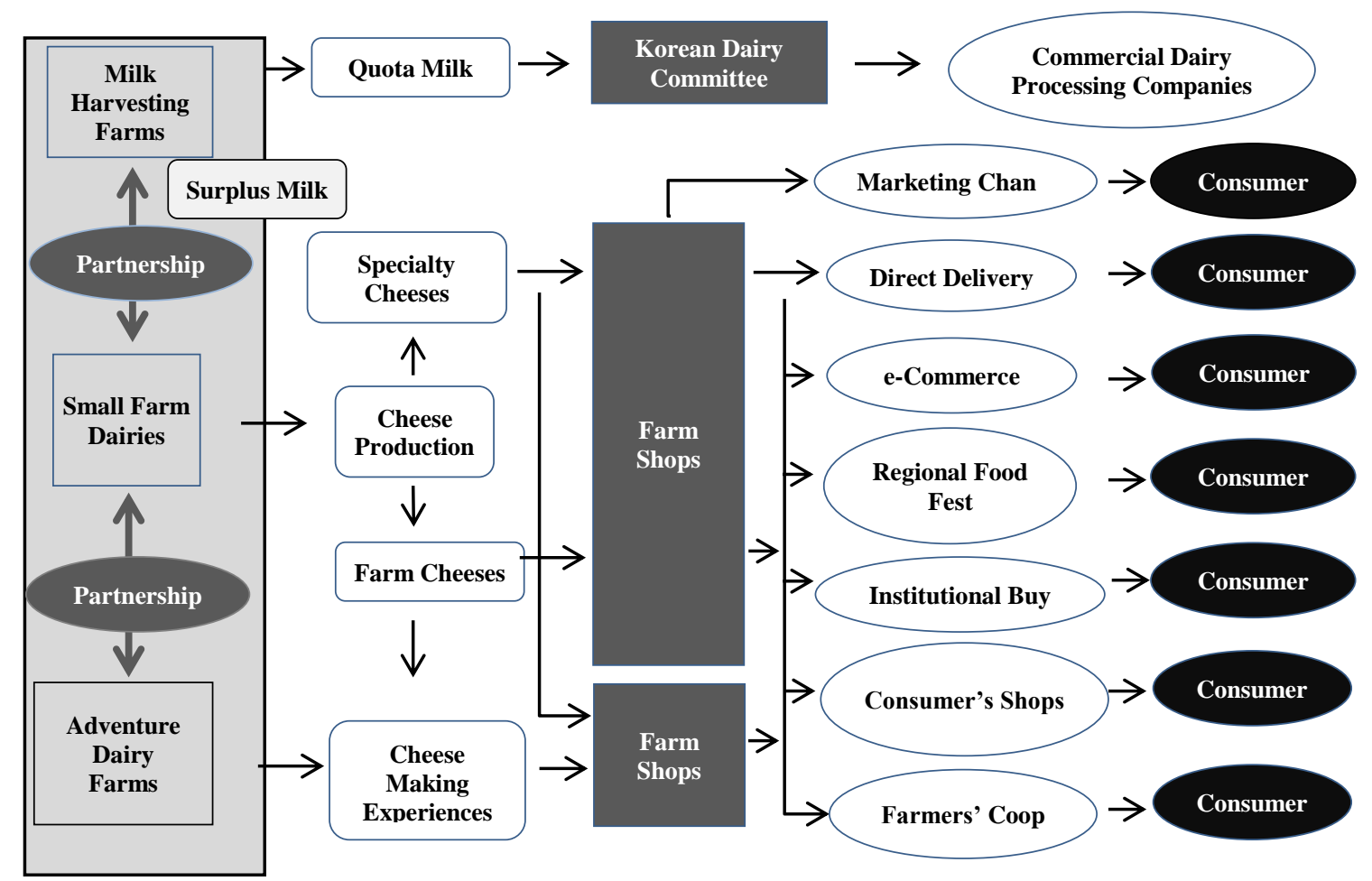

Figure 6. Strategies suggested for supply chain of farm cheese by equal partnership among dairy farms in Korea. 


\section{Conclusion}

The international situation of the dairy sector is in continuous evolution, and to predict the development milk prices in the coming decades is extremely complex, also taking into account the effects of abolishing the milk quota system in Europe. On the other hand, there is an increasingly opening of domestic markets to globalization which exposes farms to new competitors. Considering these changes in the international market, it cannot be excluded that, in the near future, the support scheme applied in South Korea, a country where the average costs of milk production are very high, will have to be modified in order to comply with world trade regulations. In addition, the milk sector is characterized by an asymmetry of price transmission along the supply chain, resulting in much lower value retained on farm than the retail price. For farmers the necessity emerges and will probably increase in the near future, to add more value to their products. The different strategies to retain added value in farms are summarized in Figure 6. In this respect short supply dairy chains, probably including direct transformation of milk into cheese and/or direct sales to consumers, seem a promising approach, considering that, in South Korea, there is a gap between supply and demand for this product. However, this is an individual strategy which is open only to certain producers. Another option is to engage into dedicated supply chains which allow certification by independent and publicly acknowledged public bodies. Such labels may increase awareness on locality and production processes applied among consumers. However, the introduction of such instruments is often beyond the influence of farmers. A third option is the formation of values based supply chains. This needs the coordination of likeminded partners along the entire chain from production to consumption and involves often the formation of small new cooperative structures, which are strongly trust based. The ultimate aim of these options is to limit conflicts between actors in the dairy chain, contribute to resolving the problem of surplus production, and mainly to contribute to the economic sustainability of Korean dairy production also in respect to imports.

Future government support programs should be take into account these options and provides assistance for farmers to progress along these lines.

\section{Acknowledgments}

This study was supported by the research project No. PJ01020902 of RDA 2015, "Study profitability of milk produced from cows grass-fed in Alpine Pasture".

\section{References}

Areté. 2013. Study on Assessing the Added Value of pdo/pgi Products. Study Commissioned by European Commission, http://ec.europa.eu/agriculture/externalstudies/2013/added-value-pdo-pgi/exec-sum_en.pdf, Accessed 18 January 2017.

Bérard, L. and P. Marchenay. 2007. Localized Products in France: Definition, Protection and Value-Adding. Anthropology of Food, https://aof.revues.org/415, Accessed 18 January 2017.

Bertazzoli, A., Fiorini A., Ghelfi, R., Rivaroli, S., Samoggia, A. and V. Mazzott. 2009. Food chains and value system: the case of potato, fruit, and cheese. Proceedings of $113^{\text {th }}$ EAAE Seminar, pp. 1-16.

Bonnet, C. and M. Simioni. 2001. Assessing Consumer Response to Protected 
Designation of Origin Labeling: a Mixed Multinomial Logit Approach. European Review of Agricultural Economics, 28:433-449.

Borreani, G., Coppa, M., Revello-Chion, A., Comino, L., Giaccone, D., Ferlay, A. and E. Tabacco. 2013. Effect of different feeding strategies in intensive dairy farming systems on milk fatty acid profile, and implications on feeding costs in Italy. Journal of Dairy Science, 96:6840-6855.

Bovolenta, S. 2007. Support for "Short Chains" in the Dairy Sector. Report to ERSA, Regional Agency for Rural Development of Friuli Venezia Giulia Region.

Bovolenta, S., Dovier, S. and G. Parente. 2011. Dairy Production System in the Italian Alpine Area, in Agroscope Research Station, ed. Proceedings of FAO CIHEAM Mountain Pastures Network Meeting, pp 137-140.

Braghieri, A., Girolami, A., Riviezzi, A.M., Piazzolla, N. and F. Napolitano. 2014. Liking of Traditional Cheese and Consumer Willingness to Pay. Italian Journal of Animal Science, e13:3029.

Caporale, G. and E. Monteleone. 2004. Influence of Information About Manufacturing Process on Beer Acceptability. Food Quality and Preference, 15:271-278.

Capps, O.J. and P. Sherwell. 2005. Spatial Asymmetry in Farm Retail Price Transmission Associated with Fluid Milk Products. Proceedings of the American Agricultural Economics Association, Province, Rhode Island, USA, http://citeseerx.ist.psu.edu/viewdoc/download?doi=10.1.1.577.1880\&rep=rep1\&typ e=pdf, accessed 18 January 2017.

CLAL. 2014. Competitiveness of Milk Price at Farm. http://www.clal.it/index.php?section=confronto_payout_pr_latte_ponderato, Accessed 18 January 2017.

Corazzin, M., Piasentier, E. and S.Y. Park. 2015. The End of the milk Quota Regime in the European Union: the Perspective of the Dairy Sector with Particular Regard to Mountain Area. Journal of Milk Science and Biotechnology, 33:171-177.

European Commission. 2015. Geographical Indications and Traditional Specialties, http://ec.europa.eu/agriculture/quality/schemes, Accessed 18 January 2017.

Dalvit, C., De Marchi, M. and M. Cassandro. 2007. Genetic Traceability of Livestock Products: A review. Meat Science, 77:437-449.

De Brito, M.M., Bánkuti, F.I., Bánkuti, S.M.S., Melo Ferreira, M.C., Damasceno, J.C., Dos Santos, G.T. and M.A. Zambon. 2015. Horizontal Arrangements: Strategy for Reducing the Asymmetry Information for Dairy Farmers in Paraná, Brazil. Ciência Rural, 45:2069-2075.

European Commission. 2009. Analysis of Price Transmission along the Food Supply Chain in the EU. Commission of the European Communities, Brussels, Belgium.

Garavaglia, C. and E.M. Marcoz. 2014. Willingness to Pay for PDO Certification: an Empirical Investigation. International Journal on Food System Dynamics, 5:11-22.

Garcia Perez, A.M. and M. Garcia Martinez. 2007. The Agri-Food Cooperative Netchain: a Theoretical Framework to Study its Configuration', Acta Agriculturae Scandinavica, Section C - Food Economics, 4:31-39.

Howard, P.H. 2006. Central Coast Consumers Want More Food Related Information, from Safety to Ethics. California Agriculture, 60:14-19.

Kapsosderová, L. and L. Nagyová. 2005. Consumer Behavior at the Slovak Dairy Market. Agriculture Econonomics - Czech, 51:362-368. 
KDC. 2015. Korea Dairy Committee. http://www.dairy.or.kr, accessed 18 January 2017. Kim, H. and R.W. Ward. 2013. Vertical Price Transmission in U.S. Dairy Products. Korean Journal of Agricultural Management and Policy, 40:381-399.

KOSIS, 2014. Korean Statistical Information Service. http://kosis.kr/eng, accessed 18 January 2017.

KREI. 2014. Agricultural prospect 2014. KREI, Seoul.

Lahne, J., Trubek, A.B. and M.L. Pelchat. 2014. Consumer Sensory Perception of Cheese Depends on Context: a Study Using Comment Analysis and Linear Mixed Models. Food Quality and Preference, 32:184-197.

Lazzarini, S.G., Chaddad, F.R. and M.L. Cook 2001. Integrating Supply Chain and Network Analysis: The Study of Netchains. Journal on Chain and Network Science, 1:7-22.

Lee, H., Sumner, D.A. and B.I. Ahn. 2006. Consequences of Further Opening of the Korean Dairy Market. Food Policy, 31:238-248.

Lees, M. 2003. Food Authenticity and Traceability. CRC Press, Boca Raton, New York.

Napolitano, F., Braghieri, A., Piasentier, E., Favotto, S., Naspetti, S. and R. Zanoli. 2010. Cheese Liking and Consumer Willingness to Pay as Affected by Information about Organic Production. Journal of Dairy Research, 77:273-279.

OECD. 2004. OECD Agricultural Policies 2004: at a Glance, Working Party on Agricultural Policies and Markets, OECD publishing, Paris.

OECD. 2014. Agricultural Policy Monitoring and Evaluation 2014: OECD Counties, OECD Publishing, Paris.

OECD-FAO. 2014. OECD-FAO Agricultural Outlook 2014-2023, OECD Publishing, Paris.

Oliveira, M.F.L., Carvalho, M.L.S., Lucas, M.R. and P.D. Henriques. 2014. Price Transmission in the Milk Portuguese Market. CEFAGE-UE working paper no. 19, http://www.cefage.uevora.pt/en/content/download/5408/63888/version/1/.../2014_1 9.pdf, Accessed 18 January 2017.

Onozaka, Y., Nurse, G. and D. Thilmany. 2010. Local Food Consumers: How Motivations and Perceptions Translate to Buying Behavior. Choices, 25:1.

Park, S.Y., Kwon, Y.W. and K.I. Sung. 2017. Research on value chain exertion of farm milk products produced on mountain pasture. In submission to Journal of the Korean Society of Grassland and Forage Science.

Pauwelyn, B. 2014. Value Chain Analysis for Organic Milk in Flanders. Thesis, University of Gent, Belgium.

Romanzin, A., Corazzin, M., Piasentier, E. and S. Bovolenta. 2013. Effect of rearing system (mountain pasture vs. indoor) of Simmental cows on milk composition and Montasio cheese characteristics. Journal of Dairy Research, 80:390-399.

Romanzin, A., Corazzin, M., Favotto, S., Piasentier, E. and S. Bovolenta. 2015. Montasio Cheese Liking as Affected by Information About Cows Breed and Rearing System. Journal of Dairy Research, 82:15-21.

Schermer, M. and C. Furtschegger. 2013. Value Based Supply Chains to Meet the Expectations of Organic Consumers - a Case Study from Austria. Proceedings of the ESRS Congress, http://orgprints.org/25181/, accessed 18 January 2017.

Schermer, M. 2015. Value Based Supply Chains for Mountain Products. The Example of BioAlpin in Tyrol/Austria. Proceedings of the Symposium of Korean Society of 
Grassland and Forage Science, Cheonan, South Korea.

Schnepf, R. 2013. Farm-to-Food Price Dynamics, Congressional Research Service, CRS Report, https://www.fas.org/sgp/crs/misc/R40621.pdf, accessed 18 January 2017.

Seo, S. 2005. Forage production and animal husbandry in Korea. Grassland Science, 51:21-25.

Stevenson, G.W. and R. Pirog. 2008. Values-Based Supply Chains: Strategies for Agrifood Enterprises of the Middle. In Food and the Mid-Level Farm: Renewing an Agriculture of the Middle. Eds., Lyson, T.A., Stevenson, G.W., and Welsh, R. Cambridge: The MIT Press, pp: 119-143.

Stewart, H. and D.P. Blayney. 2011. Retail Dairy Prices Fluctuate with the Farm Value of Milk. Agricultural and Resource Economics Review, 40:201-217.

Valeeva, N.I., Meuwissen, M.P.M., Oude Lansink, A.G.J.M. and R.B.M. Huirne. 2005. Improving Food Safety Within The Dairy Chain: An Application of Conjoint Analysis. Journal of Dairy Science, 88:1601-1612.

Van der Ploeg J.D. and D. Roep. 2003. Multifunctionality and Rural Development: the Actual Situation in Europe. In Multifunctional Agriculture: A New Paradigm for European Agriculture and Rural Development, Eds., Van Huylenbroeck, G. and G. Durand. Hampshire: Ashgate, pp: 37- 53.

Verlegh, P.W.J. and J.B.E.M. Steenkamp. 1999. A Review and Meta-Analysis of Country-of-Origin Research. Journal of Economic Psychology, 20:521-546.

Zheng, Y. 2014. Consumer Preference and Willingness to Pay for Locally Produced, Organic Food: A Stated Choice Approach. Thesis, University of Guelph, Canada. 